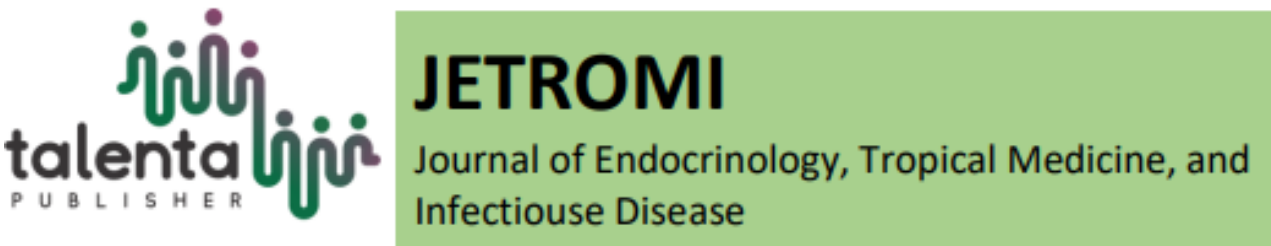

\title{
Effects of Ramadan Fasting on Lipid Profiles and Interleukin-6 in Obese Patients
}

\author{
Frihastina Lubis ${ }^{1}$, Aron Pase ${ }^{2}$ \\ ${ }^{1,2}$ Divisi Endokrinologi dan Penyakit Metabolik Departemen Ilmu Penyakit Dalam Fakultas Kedokteran \\ Universitas Sumatera Utara
}

\begin{abstract}
Obesity can cause a state of chronic low-grade inflammation due to hypertrophy and hyperplasia of adipose tissue which is not followed by the formation of balanced vascularization. Interleukin-6 is one of the mediators of inflammation that results from obesity. Changes in lifestyle during fasting for the entire month of Ramadan are thought to have an effect on the lipid profile and inflammatory mediators. This research is a prospective cohort observational study conducted in March 2019-May 2019 endocrine polyclinic outpatient clinic Haji Adam Malik Hospital Medan in 30 subjects. Anthropometric measurements and examination of lipid profiles and IL-6 levels, one week before Ramadan fasting and the fourth week of Ramadan. This study showed that there were significant differences in total cholesterol and HDL levels in the study subjects before and after Ramadan fasting ( $\mathrm{p}<0.001 ; \mathrm{p}=0.049$ ). Also found significant differences in median IL-6 study subjects before and after Ramadan fasting ( $\mathrm{p}<0.001)$. There was a decrease in levels of IL-6, a decrease in total cholesterol and a statistically significant increase in HDL in obese patients undergoing Ramadan fasting.
\end{abstract}

Keyword: Ramadan fasting; Interleukin-6, lipid profile, obesity

\begin{abstract}
Abstrak. Obesitas dapat menyebabkan keadaan inflamasi kronik derajat rendah akibat hipertrofi dan hiperplasia jaringan adiposa yang tidak diikuti oleh pembentukan vaskularisasi yang seimbang. Interleukin-6 adalah salah satu mediator inflamasi yang dihasilkan dari obesitas. Perubahan pola hidup selama berpuasa Ramadhan sebulan penuh diduga memiliki efek terhadap profil lipid dan mediator inflamasi. Penelitian ini merupakan studi observasional kohort prospektif dilaksanakan bulan Maret 2019- Mei 2019 diinstalasi rawat jalan Poliklinik Endrokrin RS Haji Adam Malik Medan pada 30 subjek. Dilakukan pengukuran antropometri dan pemeriksaan profil lipid dan kadar IL-6, satu minggu sebelum puasa Ramadhan dan pada minggu keempat Ramadhan. Penelitian ini menunjukkan bahwa terdapat pebedaan signifikan kadar kolesterol total dan HDL subjek penelitian sebelum dan setelah puasa Ramadhan ( $<<0,001 ; p=0,049)$. Dijumpai juga perbedaan bermakna median IL-6 subjek penelitian sebelum dan setelah puasa Ramadhan $(p<0,001)$. Terdapat penurunan kadar IL-6, penurunan kolesterol total dan peningkatan HDL yang signifikan secara statistik pada pasien obesitas yang menjalani puasa Ramadhan.
\end{abstract}

Kata Kunci: puasa Ramadhan; Interleukin-6, profil lipid, obesitas

Received 16 April 2020 | Revised 26 April 2020 | Accepted 11 May 2020

\footnotetext{
*Corresponding author at: Faculty of Medicine, Universitas Sumatera Utara, H. Adam Malik Hospital, Jalan Bunga Lau No 17, Medan 20136, Indonesia

E-mail address: frihastina.usu@gmail.com
} 


\section{Introduction}

Obesity is a multifactorial disease characterized by weight gain due to excessive fat accumulation. The prevalence of obesity and overweight has increased to one third of the world's population. In 2015, the prevalence of obesity was estimated at 1.9 billion people and overweight was estimated at 609 million people, which represented 39\% of the world's population [1]. Obesity can cause a low-grade chronic inflammatory state [2]. In obesity, adipocyte cells experience hypertrophy and hyperplasia, causing adipose tissue enlargement. This is not followed by the formation of a balanced vascularization that triggers adipose tissue hypoxia. Hypoxia triggers apoptosis, necrosis and activation of adipose tissue macrophages that release TNF- $\alpha$ and IL-6.[3]-[4]

Ramadan fasting is one of the five Pillars of Islam that must be implemented by every Muslim throughout the world. Some studies suggest that changes in lifestyle for a whole month (reduced frequency of large meals from 3 times to 2 times in 24 hours, increased physical activity during worship and reduced smoking time due to smoking restrictions during the day) are thought to have an effect on weight loss and process body metabolism, specifically improvement in lipid profile and decreasing inflammatory mediators [5]-[6]. Aksungar et al, [7] concluded that intermittent fasting such as Ramadan fasting has a positive effect on the body's inflammatory status and decreases the risk of cardiovascular disease. This is based on his findings that there is a significant decrease in levels of IL-6, hsCRP (high sensitive C-reactive protein) and homocysteine in people who fast Ramadan both men and women compared to controls who do not fast. Mohammadzade et al in 2017 [6] concluded there were no significant changes in IL-6 and Hs-CRP levels in subjects undergoing Ramadan Fasting.

Some of the differences in the results of the study above attracted the attention of researchers to conduct research on the effects of fasting on lipid profiles and inflammatory mediators, especially in obese patients. Researchers are interested in conducting this study in obese patients because there are very few or even no similar studies that directly examine changes in lipid profile and IL-6 levels in obese individuals who undergo Ramadan Fasting.

\section{MATERIALS AND METHODS}

\subsection{Subject}

A total of 30 obese men and women (BMI $\geq 25 \mathrm{~kg} / \mathrm{m} 2$ ) aged 20-65 years who carried out Ramadan fasting participated in this study. Obese subjects taking long-term medications (hormonal drugs, corticosteroids, anti-diabetic drugs, cholesterol-lowering drugs), acute myocardial infarction, inflammatory and malignant arthritis, and systemic diseases (diabetes mellitus, chronic kidney disease) and hormonal diseases (thyroid disease), growth hormone 
disorders, reproductive disorders, and adrenal hornon disorders) were excluded. Research subjects fasted 14 hours for 28-30 days. Informed consent was signed by all study subjects.

\subsection{Data collection and blood samples}

Venous blood samples were taken from the subject's left arm's cubital vein after fasting 10-12 hours, 1 week before Ramadan fasting (09.00-10.00 AM) and on the fourth week of Ramadan (after fasting for 21 days) at 09.00-10.00 AM. Blood samples were centrifuged to be separated with plasma, then stored in a freezer (at $-20^{\circ} \mathrm{C}$ ) for biochemical analysis. Anthropometric measurements are also carried out 1 week before Ramadan and in the fourth week of Ramadan (after fasting for 21 days). Body weight measurements (subjects using minimal clothing, removing jackets, removing accessories used and barefoot) use digital scale weight scales (Kris). Height is measured using microtoise (statuture maeter) with the subject standing straight, looking straight ahead, and barefoot. Calculation of Body Mass Index (BMI) can be calculated by the formula Weight (kg) divided by Height (m2). Waist circumference is measured by a nonelastic tape measure by measuring the length of the circumference measured between the crista illiaca and costa XII at the smallest circumference. Hip circumference is measured by a nonelastic tape measure by measuring the length of the circumference measured at the maximum circumference of the buttocks and the upper part of the sympysis pubis os. The ratio of the hip circumference is calculated by dividing the waist circumference by the hip circumference. Blood pressure is measured with a mercury spygmomanometer in $\mathrm{mmHg}$ with a quiet sitting position on the right arm in a minimum of 5 minutes rest. Examination of lipid profiles (total cholesterol, LDL, HDL) was measured using the enzymatic colorimetric method. Quantitative detection of serum IL-6 levels using the ELISA technique.

\subsection{Statistic analysis}

Analysis and presentation of data using statistical analysis with Stastical Product and Service Solution (SPSS) 22.0 for windows software. To assess whether a sample with a normal distribution or not uses the Shapiro-Wilk Test (the number of samples is below fifty). The results of the study were statistically analyzed using dependent $t$ measurements if the data were normally distributed, and if the data were not normally distributed the Wilcoxon test was used. $P$ value $<0.05$ was considered statistically significant.

\section{RESEARCH RESULT}

A total of 34 obese subjects who met the inclusion and exclusion criteria participated in this study (table 1), but at the end of the study 4 people were lost to follow up because they were not present at the re-examination after fasting Ramadan, bringing the total research subjects to 30 people . Based on gender, the majority of subjects were male, amounting to 27 people (90\%) 
while female subjects amounted to 3 people (10\%). The mean age of the subjects was $27.2 \pm 3.9$ years.

Table 1 Basic Characteristics of Research Subjects

\begin{tabular}{|c|c|}
\hline Characteristics & $\begin{array}{c}\mathbf{n}=\mathbf{3 0} \\
\text { med (min-max) }\end{array}$ \\
\hline \multicolumn{2}{|l|}{ Gender } \\
\hline Male & $27(90 \%)$ \\
\hline Girl & $3(10 \%)$ \\
\hline Age (years) ${ }^{a}$ & $27.2 \pm 3.9$ \\
\hline Systolic blood pressure $(\mathrm{mmHg})^{a}$ & $120.8 \pm 9.2$ \\
\hline Diastolic blood pressure $(\mathrm{mmHg})^{a}$ & $82.4 \pm 9.8$ \\
\hline Height $(\mathrm{cm})^{a}$ & $170.6 \pm 6.7$ \\
\hline Weight $(\mathrm{kg})^{\mathrm{a}}$ & $90.8 \pm 18.6$ \\
\hline BMI $(\mathrm{kg} / \mathrm{m} 2)^{\mathrm{b}}$ & $29.2(25.2-42.5)$ \\
\hline Waist circumference $(\mathrm{cm})^{a}$ & $100.9 \pm 13.5$ \\
\hline Pelvic circumference $(\mathrm{cm})^{a}$ & $110.3 \pm 10.8$ \\
\hline Waist / hip circumference ratio ${ }^{b}$ & $1.03(0.92-1.08)$ \\
\hline Total cholesterol (mg / dL) ${ }^{a}$ & $199.7 \pm 34.4$ \\
\hline $\mathrm{HDL}-\mathrm{C}(\mathrm{mg} / \mathrm{dL})^{\mathrm{a}}$ & $49.4 \pm 8.2$ \\
\hline $\mathrm{LDL}-\mathrm{C}(\mathrm{mg} / \mathrm{dL})^{\mathrm{a}}$ & $130.1 \pm 28.4$ \\
\hline IL-6 ${ }^{\mathrm{b}}$ & $88(28.7-781.6)$ \\
\hline \multicolumn{2}{|c|}{$\begin{array}{l}\text { BMI: body mass index ; HDL-C: High Density Lipoprotein cholesterol } \\
\text { LDL-C: Low Density Lipoprotein cholesterol }\end{array}$} \\
\hline $\begin{array}{l}\text { a normal distribution, mean } \pm \text { SD } \\
\text { b abnormal data distribution; medi }\end{array}$ & 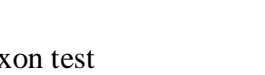 \\
\hline
\end{tabular}

\subsection{Changes in Hemodynamic and Anthropometric Parameters before and After Ramadan Fasting}

Changes in hemodynamic and anthropometric parameters before and after Ramadan fasting can be seen in Table 2.

Table 2 Changes in Hemodynamic and Anthropometric Parameters of Subjects Before and After Ramadan Fasting

\begin{tabular}{lccc}
\hline \multicolumn{1}{c}{ Characteristic } & $\begin{array}{c}\text { p1 } \\
\text { med (min-max })\end{array}$ & $\begin{array}{c}\text { p2 } \\
\text { med (min-max) }\end{array}$ & P \\
\hline SBP $(\mathrm{mmHg})^{\mathrm{a}}$ & $120.8(111.6-130)$ & $119.7(108.4-131)$ & 0.475 \\
DBP $(\mathrm{mmHg})^{\mathrm{a}}$ & $82.4(72.6-92.2)$ & $81.1(70.6-91.6)$ & 0.417 \\
${\text { Body weight }(\mathrm{kg})^{\mathrm{a}}}_{\text {BMI }\left(\mathrm{kg} / \mathrm{m}^{2}\right)^{\mathrm{b}}}$ & $90.8(72.2-109.4)$ & $89.4(70.9-107.9)$ & $0.001^{* *}$ \\
Waist size $(\mathrm{cm})^{\mathrm{a}}$ & $29.2(25.2-42.5)$ & $28.8(25.1-42.0)$ & $0.001^{* *}$ \\
Hip size $(\mathrm{cm})^{\mathrm{a}}$ & $100.9(87.4-114.4)$ & $98.7(86.7-110.7)$ & $0.016^{*}$ \\
Waist/Hip ratio $^{\mathrm{b}}$ & $110.3(99.5-121.1)$ & $108.3(98.1-118.5)$ & $0.005^{*}$ \\
\hline
\end{tabular}

BMI: body mass index; SBP : Systolic Blood Pressure DBP : Diastolic Blood Pressure

a normal data distribution; mean $\pm \mathrm{SD}$; paired $\mathrm{t}$ test

$\mathrm{b}$ abnormal data distribution; median (min-max); Wilcoxon test

$* \mathrm{p}<0.05 ; * * \mathrm{p}<0.001 ; \mathrm{P} 1$ before Ramadan fasting ; P2 after Ramadan fasting 
There were significant differences in weight and IMT of the study subjects before and after Ramadan fasting ( $<<0.001$ and $\mathrm{p}<0.05$ ) (table 2 ). There is a statistically significant reduction in weight and IMT after Ramadan fasting. Waist circumference, hip circumference, and the ratio of waist / hip subjects before and after the fasting of Ramadan also demonstrated a significant reduction. The average waist circumference of the study subjects before Ramadan fasting was $100.9 \pm 13.5 \mathrm{~cm}$ and after Ramadan fasting it was $98.7 \pm 12.0 \mathrm{~cm}(\mathrm{p}=0.016)$.

\subsection{Changes in Lipid and IL-6 Profile Before and After Ramadan}

Changes in lipid and IL-6 profiles before and after Ramadan fasting can be seen in table 4.3.

Table 3 Changes in Lipid and IL-6 Profile Subjects Research Before and After Ramadan

\begin{tabular}{|c|c|c|c|}
\hline Characteristics & Before & After & $\mathbf{P}$ \\
\hline Total Cholesterol $(\mathrm{mg} / \mathrm{dL})^{\mathrm{a}}$ & $199,7 \pm 34,4$ & $185,5 \pm 35,2$ & $0,001 *$ \\
\hline $\operatorname{HDL}(\mathrm{mg} / \mathrm{dL})^{\mathrm{a}}$ & $49,4 \pm 8,2$ & $52,5 \pm 8,5$ & $0,049^{*}$ \\
\hline $\operatorname{LDL}(\mathrm{mg} / \mathrm{dL})^{\mathrm{a}}$ & $130,1 \pm 28,4$ & $129,0 \pm 32,9$ & 0,729 \\
\hline IL-6 ${ }^{\mathrm{b}}$ & $88(28,7-781,6)$ & $67,75(23-596,8)$ & $<0,001 * *$ \\
\hline
\end{tabular}

Significant differences in total cholesterol, HDL and total HDL-cholesterol ratio were found before and after Ramadan fasting ( $<<0.001 ; \mathrm{p}=0.049 ; \mathrm{p}=0.021$ ) (table 4.2). The mean total cholesterol level of the study subjects before Ramadan fasting was $199.7 \pm 34.4 \mathrm{mg} / \mathrm{dL}$ and after Ramadan fasting it became $185.5 \pm 35.2 \mathrm{mg} / \mathrm{dL}$. The mean HDL level of the study subjects before Ramadan fasting was $49.4 \pm 8.2 \mathrm{mg} / \mathrm{dL}$ and after Ramadan fasting it became $52.5 \pm 8.5 \mathrm{mg} / \mathrm{dl}$. The mean HDL-cholesterol ratio of the total study subjects before Ramadan fasting was $0.26 \pm 0.07$ and after Ramadan fasting it became $0.30 \pm 0.09$. Significant differences were found in the median IL-6 study subjects before and after Ramadan fasting ( $\mathrm{p}<0.001)$. The median value of IL-6 also decreased from 88 (28.7-781.6) pg / $\mathrm{ml}$ before fasting to 67.75 (23596.8) pg / $\mathrm{ml}$ after fasting.

\subsection{Differences in Changes in Anthropometric and Laboratory Parameters Before and After Ramadan Fasting by Tarawih Category}

Differences in changes in anthropometric and laboratory parameters before and after Ramadan fasting based on tarawih categories can be seen in table 4 . 
Table 4 Differences in Changes in Clinical and Laboratory Parameters by Tarawih Category

\begin{tabular}{|c|c|c|c|c|c|c|c|c|c|}
\hline \multirow{2}{*}{$\begin{array}{l}\text { Characte } \\
\text { ristic }\end{array}$} & \multicolumn{2}{|c|}{$<15$ days } & \multicolumn{6}{|c|}{$>15$ days } & \multirow{2}{*}{$\Delta p$} \\
\hline & $\begin{array}{c}\text { Before } \\
\text { Med (min-max) }\end{array}$ & $\begin{array}{c}\text { After } \\
\text { Med (min-max) }\end{array}$ & $\Delta$ & P1 & $\begin{array}{c}\text { Before } \\
\text { Med (min-max) }\end{array}$ & $\begin{array}{l}\text { After } \\
\text { Med (min-max) }\end{array}$ & $\Delta$ & P2 & \\
\hline $\begin{array}{l}\text { BW } \\
(\mathrm{kg})^{\mathrm{a}}\end{array}$ & $\begin{array}{c}93.4 \\
(73.4-113.4)\end{array}$ & $\begin{array}{c}92.4 \\
(72.2-112.6)\end{array}$ & -1.03 & $0.026^{*}$ & $\begin{array}{c}88.2 \\
(70.9-105.5)\end{array}$ & $\begin{array}{c}86.3 \\
(69.6-103)\end{array}$ & -1.93 & $0.001 * *$ & 0.088 \\
\hline $\begin{array}{l}\mathrm{BMI} \\
\left(\mathrm{kg} / \mathrm{m}^{2}\right)^{\mathrm{a}}\end{array}$ & $\begin{array}{c}31.6 \pm 5.7 \\
(25.9-37.3\end{array}$ & $\begin{array}{c}31.3 \\
(25.5-37.1)\end{array}$ & -0.35 & $0.033^{*}$ & $\begin{array}{c}30.4 \\
(26.1-34.7)\end{array}$ & $\begin{array}{c}29.8 \\
(25.5-34)\end{array}$ & 0.68 & $0.001 * *$ & 0.939 \\
\hline $\begin{array}{l}\text { Waist size } \\
(\mathrm{cm})^{\mathrm{a}}\end{array}$ & $\begin{array}{c}102.2 \\
(86.7-117.7)\end{array}$ & $\begin{array}{c}100.0 \\
(86.1-113.9)\end{array}$ & -2.2 & 0.147 & $\begin{array}{c}99.6 \\
(88.1-111.1)\end{array}$ & $\begin{array}{c}97.5 \\
(87.4-107.6)\end{array}$ & -2.1 & $0.039 *$ & 0.530 \\
\hline $\begin{array}{l}\text { Hip size } \\
(\mathrm{cm})^{\mathrm{a}}\end{array}$ & $\begin{array}{c}110.7 \\
(98.9-122.5)\end{array}$ & $\begin{array}{c}108.2 \\
(97-119.4)\end{array}$ & -2.5 & $0.028^{*}$ & $\begin{array}{c}109.9 \\
(99.8-120)\end{array}$ & $\begin{array}{c}108.3 \\
(98.7-117.9)\end{array}$ & -1.6 & 0.102 & 0.077 \\
\hline $\begin{array}{l}\text { TC } \\
(\mathrm{mg} / \mathrm{dL})^{\mathrm{a}}\end{array}$ & $\begin{array}{c}200.6 \\
(173-228.2)\end{array}$ & $\begin{array}{c}190.2 \\
(166.5-213.9)\end{array}$ & -10.4 & $0.021^{*}$ & $\begin{array}{c}198.9 \\
(157.7-240.1)\end{array}$ & $\begin{array}{c}180.7 \\
(136.5-224.9)\end{array}$ & 18.1 & $0.019^{*}$ & 0.339 \\
\hline $\begin{array}{l}\mathrm{HDL} C \mathrm{C} \\
(\mathrm{mg} / \mathrm{dL})^{\mathrm{a}}\end{array}$ & $\begin{array}{c}50.5 \\
(44-57)\end{array}$ & $\begin{array}{c}52.9 \\
(45.4-60.4)\end{array}$ & 2.3 & 0.075 & $\begin{array}{c}48.3 \\
(38.6-58)\end{array}$ & $\begin{array}{c}52.1 \\
(42.4-61.8)\end{array}$ & 3.8 & 0.192 & 0.634 \\
\hline $\begin{array}{l}\text { LDL-C } \\
(\mathrm{mg} / \mathrm{dL})^{\mathrm{a}}\end{array}$ & $\begin{array}{c}131.9 \\
(109.8-154)\end{array}$ & $\begin{array}{c}131.0 \\
(107.1-154.9)\end{array}$ & -0.9 & 0.769 & $\begin{array}{c}128.3 \\
(94.1-162.5)\end{array}$ & $\begin{array}{c}127.1 \\
(86.3-167.9)\end{array}$ & -1.2 & 0.826 & 0.917 \\
\hline $\begin{array}{l}\text { IL-6 } \\
(\mathrm{pg} / \mathrm{Ml})^{\mathrm{b}}\end{array}$ & $\begin{array}{c}75.6 \\
(28.7-781.6)\end{array}$ & $\begin{array}{c}63.5 \\
(23-596)\end{array}$ & -19 & $0,001 *$ & $\begin{array}{c}89 \\
(57.4-554)\end{array}$ & $\begin{array}{c}74.3 \\
(32.3-530.4)\end{array}$ & -21 & $0.001 *$ & 0.983 \\
\hline
\end{tabular}

Significant differences in body weight were found before and after Ramadan fasting both in groups with tarawih less than 15 days and in the tarawih group for more than 15 days $(p=0.026$ vs $\mathrm{p}<0.001)$. We found a higher weight loss in the group with tarawih more than 15 days compared to the group with tarawih less than 15 days $(1.93 \pm 1.1$ vs $1.03 \pm 1.6)$, but this difference was not statistically significant $(\mathrm{p}=0.088)$.

Significant differences in body mass index were found before and after Ramadan fasting both in groups with tarawih less than 15 days and in the tarawih group for more than 15 days $(p=0.033$ vs $\mathrm{p}<0.001$ ). A decrease in body mass index was found to be higher in the group with tarawih more than 15 days compared to the group with tarawih for less than 15 days $(0.68 \pm 0.38$ vs. $0.35 \pm 0.57$ ), but this difference was not statistically significant $(\mathrm{p}=0.939)$.

Significant differences in waist circumference before and after Ramadan fasting were found in groups with tarawih for more than 15 days, but no significant differences in waist circumference in the tarawih group were less than 15 days ( $\mathrm{p}=0.039$ vs $\mathrm{p}=147$ ). The decrease in waist circumference was found to be higher in the group with tarawih less than 15 days compared to the group with tarawih for more than 15 days $(2.1 \pm 3.5$ vs $2.5 \pm 3.9)$, but this difference was not statistically significant $(\mathrm{p}=0.530)$. 
Significant differences were found in total cholesterol before and after Ramadan fasting both in groups with tarawih less than 15 days and in the tarawih group for more than 15 days $(p=0.021$ vs $p=0.019$ ). The decrease in total cholesterol was found to be higher in the group with tarawih more than 15 days compared to the group with tarawih for less than 15 days $(18.1 \pm 26.5$ vs 10.4 $\pm 15.5)$, but this difference was not statistically significant $(\mathrm{p}=0.339)$.

No significant differences were found in HDL before and after Ramadan fasting both in groups with tarawih less than 15 days and in the tarawih group for more than 15 days $(\mathrm{p}=0.075 \mathrm{vs} \mathrm{p}=$ 0.192). The increase in HDL was found to be higher in the group with tarawih more than 15 days compared to the group with tarawih for less than 15 days ( $3.8 \pm 10.8$ vs $2.3 \pm 4.7$ ), but this difference was not statistically significant $(\mathrm{p}=0.634)$.

No significant differences were found in LDL levels before and after Ramadan fasting both in groups with tarawih less than 15 days and in the tarawih group for more than 15 days $(\mathrm{p}=0.769$ vs $p=0.826$ ). The decrease in LDL levels was found to be higher in the group with tarawih more than 15 days compared to the group with tarawih for less than 15 days $(1.2 \pm 20.8$ vs $0.9 \pm$ 12.1), but this difference was not statistically significant $(\mathrm{p}=0.917)$.

Significant differences were found in IL-6 levels before and after Ramadan fasting both in groups with tarawih less than 15 days and in the tarawih group for more than 15 days $(\mathrm{p}$ $<0.001)$. A decrease in IL-6 levels was found to be higher in the group with tarawih more than 15 days compared to the group with tarawih for less than 15 days (-21 (-117 s / d -50.5) vs -19 ($198.3 \mathrm{~s} / \mathrm{d}-5,7))$, but this difference is not statistically significant $(\mathrm{p}=0.983)$.

\subsection{Correlation of Changes in BMI with Changes in Lipid Profile and IL-6}

No correlation was found with changes in BMI with changes in total cholesterol, HDL, LDL and IL-6 (table 5)

Table 5 Correlation of BMI Changes with Changes in Total Cholesterol, HDL, LDL and IL-6

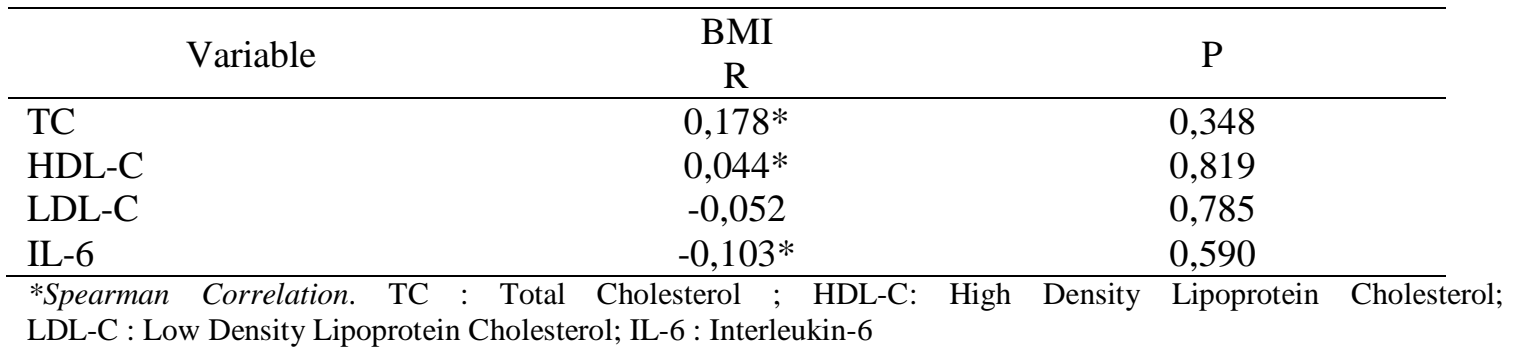

\subsection{Correlation of IL-6 Changes with Total Cholesterol and HDL Changes}

We found a weak correlation between IL-6 change and HDL change $(r=-366 ; p=0.046)$. No correlation of IL-6 changes with total cholesterol change, and LDL (table 6) 
Table 6 Correlation of Changes in IL-6 with Changes in Total Cholesterol and HDL

\begin{tabular}{lcc}
\hline \multicolumn{1}{c}{ Spearman Correlation } & IL-6 changes & \\
\cline { 2 - 3 } & $\mathrm{R}$ & $\mathrm{P}$ \\
\hline TC & $-0,291$ & 0,119 \\
HDL & $-0,366$ & $0,046^{*}$ \\
LDL & 0,009 & 0,962 \\
\hline
\end{tabular}

*Spearman Correlation

TC: total cholesterol; HDL-C: High Density Lipoprotein cholesterol,

LDL-C: Low Density Lipoprotein cholesterol; IL-6 : Interleukin-6

\section{DISCUSSION}

In this study found weight loss and BMI in obese individuals who undergo Ramadan fasting. The mean weight decreased significantly from $90.8 \pm 18.6 \mathrm{~kg}$ to $89.4 \pm 18.5 \mathrm{~kg}$ after Ramadan fasting ( $\mathrm{p}<0.001$ ). Median BMI decreased from $29.2 \mathrm{~kg} / \mathrm{m} 2$ to $28.8 \mathrm{~kg} / \mathrm{m} 2$ ( $\mathrm{p}<0.05)$. Likewise with other anthropometric parameters such as waist circumference with a mean decrease of $2.2 \mathrm{~cm}(\mathrm{p}=0.016)$, a decrease in mean hip circumference of $2 \mathrm{~cm}(\mathrm{p}=0.005)$ and a decrease in the mean waist / hip circumference ratio of $100.9 \pm 13.5 \mathrm{~cm}$ to $98.7 \pm 12.0 \mathrm{~cm}(\mathrm{p}=$ 0.016). Weight loss is thought to be due to a decrease in calorie intake during Ramadan fasting. This was found in the study of Shariatpanahi et al, where a decrease in the average body weight of $1.96 \pm 1.35 \mathrm{~kg}$ was accompanied by a decrease in caloric intake of $234.6 \pm 88.2 \mathrm{~kJ}$ per day [8]. The majority of other studies also received the same results. Mazidi et al. in [9] a systematic review of the effects of Ramadan fasting on cardiometabolic and anthropometric parameters reported that of 16 studies on Ramadan fasting from 1982 to 2012, 10 of them found weight loss after Ramadan fasting, while a decrease in BMI was found in 6 studies. Apart from changing the frequency of eating, during fasting also changes in sleep patterns. Changes in sleep patterns cause changes in levels of leptin, neuropeptide- $Y$ and insulin which play an important role in the long-term regulation of appetite and energy intake [8].

In this study found positive effects of Ramadan fasting on lipid profiles include a decrease in total cholesterol and an increase in HDL of research subjects after Ramadan fasting ( $p<0.001 ; p$ $=0.049)$. LDL levels did not change significantly. A meta-analysis by Mirmiran et al. [10] Conducted an analysis of 33 studies from the Pubmed, Scopus and Embase databases on the effect of Ramadan fasting on lipid profile parameters found that Ramadan fasting had a positive effect on serum HDL-C both in healthy individuals, pregnant women and athletes. Significantly higher HDL increases were found in males compared to females $(2.18 \mathrm{mg} / \mathrm{dl} \mathrm{vs} 0.23 \mathrm{mg} / \mathrm{dl})$. The study of Shehab et al. [5] Concluded that Ramadan fasting or a similar dietary pattern, has a positive effect on improving lipid profile by increasing HDL levels and reducing LDL levels. Participants consisted of 60 adults (42 men and 18 women), measurements were taken on the first day of fasting (pre-Ramadan), the last day of fasting (Ramadhan) and 4 weeks after the end of Ramadan fasting (post-Ramadan). The result was that the increase in HDL-C increased significantly followed by a decrease in LDL-C in both men and women $(\mathrm{P}=0.001)$. However, 
improvements in HDL-C and LDL-C were not followed by good changes in total cholesterol and triglycerides. This is thought to be due to consumption of foods with high saturated fatty acid content during Ramadan, however data on calorie intake and types of food during Ramadan are not collected so this conjecture cannot be confirmed.

The median value of IL-6 decreased from 88 (28.7-781.6) before fasting to 67.75 (23-596.8) after fasting. Changes in IL-6 values correlate with changes in HDL, but do not correlate with changes in BMI. Faris et al. in 2012 [11] observed changes in body weight, body fat percentage, pro-inflammatory cytokine levels and the number of immune cells in people who fasted Ramadan. Blood samples are taken one week before fasting, the third week of fasting and one month after stopping fasting. The results found include, a decrease in IL-1 $\beta$, IL- 6 and TNF- $\alpha$ when fasting compared before fasting and after 1 month stopping fasting ( $\mathrm{p}<0.05)$. The mean IL-6 level before fasting $(155.85 \pm 121.18)$ decreased to $(67.42 \pm 51.25 ; \mathrm{p}<0.001)$ during fasting and again increased slightly to $(109.6 \pm 75.6$; $\mathrm{p}<0,05)$ after fasting. Calorie intake did not change significantly when fasting, but body weight and fat percentage were found to decrease significantly when fasting. Researchers suspect the relationship between decreased IL6 and weight loss, because IL-6 and TNF- $\alpha$ are inhibitors of lipoprotein lipase (LPL) which catalyzes free fatty acids. Decreased levels of IL-6 and TNF- $\alpha$ cause free fatty acid buildup. In addition, the decrease in blood sugar during fasting stimulates the production of free fatty acids from adipose tissue to support energy production. Aksungar et al. in 2007 [7] concluded that intermittent fasting such as Ramadan fasting has a positive effect on the body's inflammatory status and decreases the risk of cardiovascular disease.

This study showed significant differences in body weight and BMI before and after Ramadan fasting both in groups with tarawih for less than 15 days and in the tarawih group for more than 15 days ( $\mathrm{BW}(\mathrm{p}=0.026$ vs $\mathrm{p}<0.001)$; BMI $(\mathrm{p}=0.033)$ vs $\mathrm{p}<0.001)$ ). Patients who had tarawih prayers for 15 days or more showed greater weight loss and BMI than those who were taking tarawih for less than 15 days (BB $1.93 \pm 1.1$ vs $1.03 \pm 1.6$ ]; BMI ( $0.68 \pm 0.38$ vs. $0.35 \pm 0.57$ ), but this difference is not statistically significant $(B B p=0.088$ and BMI $p=0.939)$ This may be related to increased physical activity during the tarawih prayer [5]. There is no specific research to examine this, but there is one study that gets changes in body composition after 20 days of fasting and tarawih prayer regularly. The body composition is measured by means of bioelectrical impedance analysis (BIA) and found an increase in basal metabolic rate and lean body mass and a significant decrease in body fat and glucose levels $(\mathrm{p}<0.05)$ This indicates that Ramadan fasting and tarawih prayer can improve body composition and be of general benefit to health [12].

This study is the first study to assess changes in lipid profile and IL-6 levels in obese patients who are fasting in Ramadan. However, this study also has limitations including the small number of samples, the absence of a control group (the group that is not fasting Ramadan) as a 
comparison. The value obtained is a comparison of the basic value with the value found after the fasting of Ramadan. In addition, there is no calculation of daily calorie intake, recording of dietary habits, types of food eaten, the degree of daily activity and sleep patterns that may be correlated with research results or can also cause bias.

\section{CONCLUSION}

There was a decrease in body weight, BMI, waist circumference, hip circumference, and waist / hip circumference ratio, a decrease in total cholesterol levels, IL-6, a statistically significant increase in HDL in obese patients undergoing Ramadan fasting, whereas LDL levels also decreased but Not statistically significant There was a significant decrease in body weight, BMI, hip circumference, total cholesterol and IL-6 in groups with tarawih more than 15 days than in the tarawih group for less than 15 days. No correlation was found with changes in BMI with changes in total cholesterol, HDL, LDL and IL-6. Weak correlation was found between changes in IL-6 and changes in HDL.

\section{REFERENCES}

[1] Chooi, Y. C., Ding, C. \& Magkos, F, “ The Epidemiology Of Obesity,” Metabolism : Clinical And Experimental, vol. 53, pp. 66-10. 2018.

[2] Lafontan M. Fat Cells: Afferent And Efferent Messages Define New Approaches To Treat Obesity. Annu Rev Pharmacol Toxicol, vol 45, pp. 119-46. 2004.

[3] Cinti, S., Mitchell, G., Barbatelli, G., Murano, I., Ceresi, E., Faloia, E., et al. Adipocyte Death Defines Macrophage Localization and Function in Adipose Tissue of Obese Mice and Humans. J Lipid Res, vol 46, pp. 47-55. 2005.

[4] Ellulu, M.S., Khaza'ah, H., Abed, Y., Rahmat, A., Ismail, P., Ranneh, Y. Role of Fish Oil in Human Health and Possible Mechanism to Reduce the Inflammation. Inflammopharmacology, vol 23, pp. 79-89. 2015.

[5] Shehab, A., Abdulle, A., El-Issa, A., Al-Suwaidi, J., Nagelkerke., Favorable Changes in Lipid Profile : the Effect of Fasting after Ramadhan. Plos One, 7(10):e47615, 2012.

[6] Mohammadzade, F., Vakili, M.A., Seyediniaki, A., Amirkhanloo, S., Farajolahi, M. Akbari, H., et al., Effect of Prolonged Intermittent Fasting in Ramadan on Biochemical and Inflammatory Parameters of Healthy Men. Journal of Clinical and Basic Research (JCBR), 1(1):38-46, 2017.

[7] Aksungar, F. B., Topkaya, A. E., dan Akyildiz, M., Interleukin-6, C-Reactive Protein and Biochemical Parameters during Prolonged Intermittent Fasting. Ann Nutr Metab, 51:88-95, 2007.

[8] Shariatpanahi, Z.V., Shariatpanahi, M.V., Shahbazi, S., Hossaini, A., Abadi, A., Effect of Ramadan Fasting on Some Indices of Insulin Resistance and Components of the Metabolic Syndrome in Healthy Male Adults. British Journal of Nutrition, 100(1):147-51, 2008.

[9] Mazzatti D., Lim, F.L., O’Hara, A., Wood, I.S., Trayhum, P., A Microarray Analysis of the Hypoxia-Induced Modulation of Gene Expression in Human Adipocytes. Arch Physiol Biochem, 118:112-20, 2012.

[10] Mirmiran, P., Zahra, B., Gaeini, Z., Moslehi, N., Azizi, F., Effects of Ramadan Intermittent Fasting on Lipid and Lipoprotein Parameters: An Updated Meta-Analysis. Nutrition, Metabolism \& Cardiovascular Diseases. 29(9):906-15, 2019. 
[11] Faris, M.A.E., Kacimi, S., Al-Kurd, R.A., Fararjeh, M.A., Bustanji, Y.K. Mohammad, M.K et al., Intermittent Fasting During Ramadan Attenuates Proinflammatory Cytokines and Immune Cells in Healthy Subjects. Nutrition Research Elsevier, 32:947-55, 2012.

[12] Mokhtar, M.S. dan Ibrahim, F., Assessment of Salat Taraweeh and Fasting Effect on Body Composition. In: 4th Kuala Lumpur International Conference on Biomedical Engineering 2008, Biomed 2008, Kuala Lumpur, 2008. 